Eğitim Teknolojisi kuram ve uygulama Kış 2018 Cilt 8 Sayı 1

Winter 2018 Volume 8 Issue 1

\title{
Educational Technology theory and practice
}


Cilt 8, Sayı 1, Kış 2018

Volume 8, Issue 1, Winter 2018

Genel Yayın Editörü / Editor-in-Chief: Dr. Halil İbrahim YALIN Editör / Editor: Dr. Tolga GÜYER

Sorumlu Yazı İşleri Müdürü / Publisher Editor: Dr. Tolga GÜYER Redaksiyon / Redaction: Dr. Tolga GÜYER

Dizgi / Typographic: Dr. Tolga GÜYER

Sayfa Tasarımı / Page Design: Dr. Tolga GÜYER

Kapak Tasarımı / Cover Design: Dr. Bilal ATASOY

iletişim / Contact Person: Dr. Aslıhan KOCAMAN KAROĞLU

Dizinlenmektedir / Indexed in: ULAKBiM Sosyal ve Beşerî Bilimler Veritabanı, Türk Eğitim İndeksi

ETKU Dergisi 2011 yılından itibaren yılda iki defa düzenli olarak yayınlanmaktadır.

Educational Technology Theory and Practice Journal is published regularly twice a year since 2011.

Dr. Abdullah Kuzu
Dr. Ana Paula Correia
Dr. Aytekin Işman
Dr. Buket Akkoyunlu
Dr. Cem Çuhadar
Dr. Deniz Deryakulu

Dr. Deniz Deryakulu

\section{Editör Kurulu / Editorial Board*}

Dr. Deepak Subramony
Dr. Feza Orhan
Dr. H. Ferhan Odabaşı
Dr. Hafize Keser
Dr. Halil Ibrahim Yalın
Dr. Hyo-Jeong So

$$
\begin{aligned}
& \text { Dr. Kyong Jee(Kj) Kim } \\
& \text { Dr. M. Yaşar Özden } \\
& \text { Dr. Mehmet Gürol } \\
& \text { Dr. Özcan Erkan Akgün } \\
& \text { Dr. S. Sadi Seferoğlu } \\
& \text { Dr. Sandie Waters }
\end{aligned}
$$

Dr. Servet Bayram Dr. Şirin Karadeniz Dr. Tolga Güyer Dr. Trena Paulus Dr. Yavuz Akpınar Dr. Yun-Jo An
Dr. Abdullah Kuzu Dr. Adile Aşkım Kurt Dr. Agah Tuğrul Korucu Dr. Arif Altun Dr. Aslıhan İstanbullu Dr. Aslıhan Kocaman Karoğlu Dr. Ayça Çebi Dr. Ayfer Alper Dr. Aynur Kolburan Geçer Dr. Ayşegül Bakar Çörez Dr. Bahar Baran Dr. Berrin Doğusoy Dr. Bilal Atasoy Dr. Çelebi Uluyol Dr. Demet Somuncuoğlu Özerbaş Dr. Deniz Atal Köysüren Dr. Deniz Mertkan Gezgin Dr. Ebru Kılıç Çakmak Dr. Ebru Solmaz Dr. Ekmel Çetin Dr. Emin Ibili Dr. Emine Cabı Dr. Emine Şendurur Dr. Erinç Karataş Dr. Erhan Güneş Dr. Erkan Çalışkan Dr. Erkan Tekinarslan Dr. Erman Yükseltürk Dr. Erol Özçelik

\section{Hakem Kurulu / Reviewers}

Dr. Ertuğrul Usta

Dr. Esma Aybike Bayır

Dr. Fatma Bayrak

Dr. Fatma Keskinkılıç

Dr. Fezile Özdamlı

Dr. Filiz Kalelioğlu

Dr. Funda Erdoğdu

Dr. Gizem Karaoğlan Yılmaz

Dr. Gökçe Becit İşçitürk

Dr. Gökhan Akçapınar

Dr. Gökhan Dağhan

Dr. Gülfidan Can

Dr. H. Ferhan Odabaşı

Dr. Hafize Keser

Dr. Halil Ersoy

Dr. Halil İbrahim Akyüz

Dr. Halil Ibrahim Yalın

Dr. Halil Yurdugül

Dr. Hasan Çakır

Dr. Hasan Karal

Dr. Hatice Durak

Dr. Hatice Sancar Tokmak

Dr. Hüseyin Bicen

Dr. Hüseyin Çakır

Dr. Hüseyin Özçınar

Dr. Hüseyin Uzunboylu

Dr. Işıl Kabakçı Yurdakul

Dr. İbrahim Arpacı

Dr. İlknur Resioğlu

Dr. Kerem Kılıçer
Dr. Kevser Hava

Dr. M. Emre Sezgin

Dr. M. Fikret Gelibolu

Dr. Mehmet Akif Ocak

Dr. Mehmet Barış Horzum

Dr. Mehmet Kokoç

Dr. Melih Engin

Dr. Meltem Kurtoğlu

Dr. Mukaddes Erdem

Dr. Mustafa Serkan Günbatar

Dr. Mutlu Tahsin Üstündağ

Dr. Nadire Çavuş

Dr. Necmi Eşgi

Dr. Nezih Önal

Dr. Nuray Gedik

Dr. Nurettin Şimşek

Dr. Onur Dönmez

Dr. Ömer Faruk İslim

Dr. Ömer Faruk Ursavaş

Dr. Ömür Akdemir

Dr. Özcan Erkan Akgün

Dr. Özden Şahin İzmirli

Dr. Özlem Çakır

Dr. Ramazan Yılmaz

Dr. Recep Çakır

Dr. Sami Acar

Dr. Sami Şahin

Dr. Selay Arkün Kocadere

Dr. Selçuk Karaman
Dr. Selçuk Özdemir
Dr. Serap Yetik
Dr. Serdar Çiftçi
Dr. Serçin Karataş
Dr. Serkan Şendağ
Dr. Serkan Yıldırım
Dr. Serpil Yalçınalp
Dr. Sibel Somyürek
Dr. Soner Yıldırım
Dr. Şafak Bayır
Dr. Şahin Gökçearslan
Dr. Şeyhmus Aydoğdu
Dr. Şirin Karadeniz
Dr. Tayfun Tanyeri
Dr. Turgay Alakurt
Dr. Tolga Güyer
Dr. Türkan Karakuş
Dr. Uğur Başarmak
Dr. Ümmühan Avcı Yücel
Dr. Ünal Çakıroğlu
Dr. Veysel Demirer
Dr. Vildan Çevik
Dr. Yalın Kılıç Türel
Dr. Yasemin Demirarslan Çevik
Dr. Yasemin Gülbahar
Dr. Yasemin Koçak Usluel
Dr. Yavuz Akbulut
Dr. Yusuf Ziya Olpak
Dr. Yüksel Göktaş

\section{İletişim Bilgileri / Contact Information}

Internet Adresi / Web: http://dergipark.gov.tr/etku

E-Posta / E-Mail: tguyer@gmail.com

Telefon / Phone: +90 (312) 2021738

Belgegeçer / Fax: +90 (312) 2028387

Adres / Adress: Gazi Üniversitesi, Gazi Eğitim Fakültesi, Bilgisayar ve Öğretim Teknolojileri Eğitimi Bölümü 06500 Teknikokullar - Ankara / Türkiye 


\title{
PRENSKY’NIN “ÇOCUKLARIN DÜNYALARINI GELIŞTIRME EĞiTIMI” YAKLAŞIMI KAPSAMINDA TÜRKIYE IÇIN POTANSIYELLERIN INCELENMESI
}

\author{
Halit ARSLAN ${ }^{1}$, Yusuf Levent ŞAHIN ${ }^{2}$, H. Ferhan ODABAŞI ${ }^{3}$
}

\begin{abstract}
Öz
Prensky; günümüz çocuklarının gerçek dünya problemleriyle yüzleştikleri takdirde, sahip oldukları becerilerle bu sorunlara çözüm üretebileceklerini ifade eden bir yaklaşım ortaya atmıştır (Prensky ve Kuzu Demir, 2017). Çocukların Dünyalarını Geliştirme Eğitimi (ÇDGE) adındaki bu yaklaşım henüz Türkiye' de çok fazla bilinmemekle birlikte bu konuda son zamanlarda bir araştırmanın yapılmadığı görülmektedir. Bu çalışmada ÇDGE'nin Türkiye'de uygulanması sürecinde katkı sağlayabilecek potansiyellerin fırsatları ve engelleri incelenmiştir. Bu yaklaşıma katkı sağlayacağına inanılan Türkiye'deki potansiyeller belirlenmiş ve bu potansiyellerin verimini düşüren problemler tespit edilmiştir. ÇDGE'nin Türkiye'de uygulanabilmesi konusunda katkı sağlayacak kurumlar; Milli Eğitim Bakanlığı (MEB), Türkiye Bilimsel ve Teknolojik Araştırma Kurumu (TÜBITAK) ve Yükseköğretim Kurulu (YÖK) olarak belirlenmiştir. MEB kapsamında; Değerler Eğitimi, Bilim ve Sanat Merkezleri, Bilişim Teknolojileri ve Yazıım Dersi, Teknoloji ve Tasarım Dersi, Fatih Projesi ve STEM uygulamaları incelenmiştir. TÜBITAK kapsamında; TÜBITAK Araştırma Projeleri ve Bilim Fuarları incelenmiştir. YÖK kapsamında ise Çocuk Üniversiteleri projesinin artı ve eksi yönleri ele alınmıştır. Elde edilen veriler doğrultusunda, ÇDGE'nin Türkiye'de uygulanabilirliği konusunda önemli potansiyellerin olduğu ancak bu potansiyellerin değerlendirilmesinde çeşitli engellerin de bulunduğu, bilgisine ulaşılmıştır. Elde edilen bilgiler doğrultusunda öneriler getirilmiştir.
\end{abstract}

Anahtar Kelimeler: Çocuklar; Çocukların Dünyalarını Geliştirme Eğitimi; Prensky; Türkiye; Potansiyeller.

\footnotetext{
${ }^{1}$ Doktora Öğrencisi, Anadolu Üniversitesi, halitarslan@anadolu.edu.tr

${ }^{2}$ Yrd. Doç. Dr., Anadolu Üniversitesi, ylsahin@anadolu.edu.tr

${ }^{3}$ Prof. Dr., Anadolu Üniversitesi, fodabasi@anadolu.edu.tr
} 


\title{
EXAMINING TURKEY'S POTENTIALS WITHIN THE SCOPE OF PRENSKY'S “EDUCATION TO BETTER THEIR WORLD” PROPOSAL
}

\begin{abstract}
Prensky has introduced a proposal saying that if today's children confront real-world problems, they will be able to solve these problems with the skills they have (Prensky \& Kuzu Demir, 2017). This proposal, Education to Better Their World (Çocukların Dünyasını Geliştirme Eğitimi, ÇDGE ), is not widely known in Turkey yet, and no research has been done. This study examines the opportunities and obstacles of the potentials that could contribute to the process of implementing the ÇDGE proposal in Turkey. The potentials that could contribute to this proposal in Turkey have been identified, and problems that reduce the efficiency of these potentials have been identified. The Ministry of National Education (MEB), the Scientific and Technological Research Council of Turkey (TUBITAK) and the Council of Higher Education (YÖK) are institutions that will contribute to the implementation of this proposal in Turkey. Within the scope of MEB; Values Education, Science and Art Centers, Information Technologies and Software Course, Technology and Design Course, Fatih Project, and STEM applications were examined. Within the scope of TUBITAK; TUBITAK Research Projects and Science Fairs were examined. Within the scope of YOK, the positive and negative aspects of the Projects of the Children's Universities are discussed. The obtained data shows that the ÇDGE proposal has significant potentials on applicability in Turkey, but there are various obstacles in the evaluation of these potentials. Suggestions have been made based on the information obtained.
\end{abstract}

Keywords: Children; Education to Better their World; Prensky; Turkey; Potentials.

\section{Summary}

The generation born after 2000 and the children of present is called Generation Z. Çetin, Aydın and Başol (2014) expressed that Generation $Z$ is more successful in creativity than the other generations. However, it is necessary to provide the Generation $Z$ with great potential to realize their positive sides by using correct instructions and use their capacity for the benefits of the society.

Prensky, contributing to the range dramatically in reconstruction of the learning processes, came up with a proposal called Education to Better Their World (ÇDGE) (Prensky and Kuzu Demir, 2017). This proposal expresses that children of present day are able to produce o solution for these problems by means of their abilities if they face the problems of the real world. Elders have duty assisting children with these potentials. The instructions of the teachers, contributing to children's minds strengthfully and supporting their students like a team coach, are important. The student, trying to meet the world that he lives in will begin looking out of a different window and see the problems of the world in full capacity, by means of his teacher's correct assistance.

Some of the institutions related with the applicability of the ÇDGE proposal in Turkey are brought forward. In this study, potentials and obstacles of that enable the process of the application of ÇDGE proposal were investigated. The institutions that will contribute to the 
application of ÇDGE proposal in Turkey are determined as it is stated below; The Ministry of National Education (MEB), The Scıentıfic and Technological Research Councıl of Turkey (TUBITAK) and Council of Higher Education.

In this research, the six titles of the MEB have been examined as a potential in Turkey in terms of ÇDGE proposal. These are; values education, which aims to educate students as good citizens who have gained basic human values. Science and Art Centers (BILSEM) which aiming to find special talented students in Turkey and discover their potentials. FATIH Project, which is aiming to provide equal opportunity in education. STEM applications, which is an educational approach blending science, technology, engineering and mathematics. Information Technologies, Software Courses, also Technology, and Design Courses. However, some obstacles seen in terms of this potential. Values education is not a separate lesson; BiLSEM's trainings carrying out in late hours; Information Technology and Software and Technology and Design courses are not appreciated; The deficiencies of FATIH Project; The fact that STEM has not fully adapted to Turkey yet.

TUBITAK's two topics were examined because they were considered as the potential for ÇDGE in Turkey. These are Science Fairs and TUBITAK Research Projects. TUBITAK supports young researchers with its projects and financial possibility on their studies. The students at 5th - 12th grades do research about subjects they determined in line with their interests and they exhibit the results of their searches in TUBITAK Science Fairs. On the other hand, in TUBITAK research projects, the students present their projects, which they developed with their knowledge, skill and original ideas with the support of the advisors. However, high cost, the schools, which are not well prepared, and insufficient fairs are some of the obstacles of this potential.

Within the structure of YÖK, Children's Universities Project were examined because they were considered as the potential of ÇDGE proposal in Turkey. It is believed that The Children's Universities Project which was created within the structure of universities, with the aim of meeting young brains science and art at early age will contribute with regards to development of society, in addition to enjoy university life. However, this application project has not yet been heard adequately in our country and it has not been integrated in education, which we observe as a problem. As a result, when the potentials about ÇDGE proposals in Turkey are considered, some problems are confirmed but generally, there seems a positive scene. Thanks to the important institutions and projects, which contributes the availability of this approach in Turkey, thus the worlds of children in Turkey will improve and get better. 


\section{Giriş}

Teknolojik gelişmeler birçok alanda olduğu gibi eğitim alanında da topluma katkı sağlamaya devam etmektedir. Öğrenme ve öğretme araçlarının değişmesi ve gelişmesinin yanında eğitime yönelik düşünceler de değişim göstermekte, ihtiyaçlar ve öncelikler zamanla farklılaşmaktadır. Eğitim bir toplumun temel taşıdır ve eğitimde atılan adımlar o toplumun gelişiminin göstergesidir. Erdem (2004) sadece değişmekte ve gelişmekte olan toplumların değil, gelişmiş toplumların da dünya hayatının gereklerine ayak uydurabilmek ve karşılaşılabilecek sorunların çözümünde eğitimi daha etkin kullanabilmek maksadıyla eğitimde reformun önemli bir anekdot olduğunu ifade etmiştir. Eğitimin ve eğitimi kolaylaştıran en önemli etmenlerden biri olan teknolojinin bir hedefe birlikte yürüyen iki kardeş gibi olması nedeniyle teknolojinin eğitim ortamında kullanımı, eğitim çıktılarının artmasına, nitelik ve nicelik yönünden daha kaliteli bir hale gelmesine katkı sağlamıştır (Khurmyet, 2016). Bunun yanında teknolojinin yansıttığı değişimler öğrenme ve öğretme sürecinde öğretmenin sınıftaki rolünü değiştirerek, bilgi aktaran şahıs yerine, öğrencilerin neyi, nasıl, nereden öğrenip uygulayabileceklerine rehberlik eden kişilere dönüştürmektedir (Şimşek, 1997).

2000 yılından sonra doğan ve genel anlamda günümüzün çocuklarını kapsayan kuşağa Z kuşağı adı verilmektedir. Erdem Okumuş'un (2016) yaratıcı aktiviteleri, değişimi, yenilikleri ve dönüşümü seven işbirlikçi bireyler olarak ifade ettiği Z kuşağı, önceki kuşaklar gibi teknolojiyi sonradan gören ve öğrenen bireyler değil, direk teknolojinin içinde doğup gelişmekte olan bireylerdir. Çocuklar büyümeye başladıkça bireyin toplum olgusu gelişir ve toplumsal yaşamın niteliğini yükseltmede bireysel sorumlulukları daha çok fark ederler. Benlik algısını geliştirmede topluma hizmet etmenin önemini kavrarlar (Hayta Önal, 2005). Ülkelerin geleceği çocukların, yani günümüzün $Z$ kuşağının gelecekte iyi birer insan olabilmeleri için, topluma yararlı, toplumsal sorunlara duyarlı bir vatandaş olmayı öğrenmeleri gerekmektedir. Çetin Aydın ve Başol (2014) da Z kuşağının yaratıcılık konusunda diğer kuşaklardan daha başarılı oldukları öngörüsünde bulunmuşlardır. Ancak burada önemli nokta büyük potansiyele sahip Z kuşağının doğru yönlendirmelerle bu artı yönlerinin farkına varmalarını sağlamak ve bu cevherleri toplum yararına kullanmaktır.

Öğrenme süreçlerinin yeniden yapılandırılmasıyla ilgili, alana önemli katkılar sağlayan Prensky "Çocukların Dünyalarını Geliştirme Eğitimi" (ÇDGE) adıyla bir yaklaşım ortaya atmıştır (Prensky ve Kuzu Demir, 2017). Bu yaklaşımın temeli; Prensky'nin "Dijital Yerli” (Prensky, 2001a) adını verdiği teknoloji ile doğan ve teknolojiyle yetişen günümüz çocuklarının gerçek dünya problemleriyle yüzleşmeleri sağlanarak sahip oldukları becerilerle bu sorunlara çözüm üretebilecekleri inancı üzerine kuruludur. ÇDGE yaklaşımında çocuklar, mevcut bilgi birikimlerini kullanmalarına rehberlik edecek eğitmenler yardımıyla çevrelerindeki problemlere yönelik çözüm üretebilecek yetiye sahip bireylere dönüşebilirler, üreten ve üretken bir nesil olabilirler. Prensky mevcut eğitim yaklaşımını ve ÇDGE yaklaşımını Şekil 1'de şu şekilde açıklamıştır (Prensky ve Kuzu Demir, 2017). 




Şekil 1. Eğitim Yoluyla Dünyayı Geliştirmenin Daha İyi Bir Yolu

Bilgisayar ve internet gibi teknolojilerin olmadığı zamanları hiç bilmeyen ve yaşamları süresince daima teknolojik araçları kullanarak yetişen günümüz çocuklarının yetişme tarzları onların dünyaya bakış açılarını, yaşam tarzlarını, algılarını ve beklentilerini önemli derecede etkilemiştir (Prensky, 2001b). Bu farklılıkların eğitim sürecine de yansıdığı görülmektedir. Prensky (2005) günümüzde öğrencilerin, eski nesil öğretmenlerin küçük sürümleri olmaktan çıktığını ve öğrencilerin bu öğretmenlerden çok daha farklı öğrenme şekline sahip olduklarını belirtmektedir (Bilgiç, Duman ve Seferoğlu, 2011). Günümüz öğrencileri yeni karşılaştıkları bir materyalin kendilerine öğretilmesini beklemektense, o materyali keşfederek kendi kendilerine öğrenirler. Yani kılavuza ihtiyaç duymadan materyalin kendi kendini öğretmesini tercih ederler (Prensky, 2005; Akt: Bilgiç, Duman ve Seferoğlu, 2011). Çünkü günümüz çocuklarının artık "Eyleme geçmeden önce yetişkinlerin öğretimine ihtiyaç duyan çocuklar" olmadıkları görülmektedir (Prensky ve Kuzu Demir, 2017). Dolayısıyla Şekil 1'de de belirtildiği gibi, çocukları ham içerikle buluşturma anlayışı yerini çocukları problemle yüzleştirerek çözüm üretmelerine olanak sağlayan anlayışa bırakmaktadır.

Dünyayı daha iyi bir hale getirecek projeleri temeline alan ÇDGE yaklaşımın matrisini Şekil 2'deki görselle ifade edebiliriz (Prensky, 2016).

\begin{tabular}{|c|c|c|c|c|}
\hline & Etkili Düşünme & Etkili Eylem & Etkili ilişkiler & $\begin{array}{l}\text { Küresel ve Yerel } \\
\text { Farkındalık }\end{array}$ \\
\hline STEM & \multicolumn{4}{|c|}{ GERÇEK - DÜNYA ERIşisi } \\
\hline SOSYAL BILIMLER & \multicolumn{4}{|c|}{ EYLEMSEL TUTKU + KÜRESEL Ve YEREL GEREKSiNIMLERE dayalı } \\
\hline SANAT & \multicolumn{4}{|c|}{ BIREYSEL ve TAKIM ÇÖZÜMLERi } \\
\hline
\end{tabular}

Şekil 2. Çocukların Dünyalarını Geliştirme Eğitimi Yaklaşımı Matrisi

Şekil 2'de de görüldüğü üzere ÇDGE yaklaşımı tüm öğrencilerin gereksinim duydukları becerilere dayalı yapısıyla farklılık göstermektedir. Öğrencilerin genel anlamda gereksinim duydukları beceriler (etkili düşünme, etkili eylem, etkili ilişkiler ve küresel - yerel farkındalıklar) ile bazı öğrencilerin özelinde ihtiyaç duyulabilecek STEM, Sosyal Bilimler ve Sanat becerileri bu projenin desteklenmesi adına önem arz etmektedir (Prensky ve Kuzu Demir, 2017). Bireysel farklılıkların zenginliklerinden beslenen bu yaklaşımda günümüz öğretmenlerine düşen, 
öğrencilerine derslerde düz anlatımlar yapmak değil, onları belirli bir kalıba sokmadan bağımsız düşünmelerine olanak sağlayarak potansiyellerini ortaya çıkarmalarını sağlamaktır. Öğrencisine takım koçu gibi destek olarak, düşüncelerine güçlendirici katkı sağlayan öğretmenlerin yönlendirmeleri çok önemli bir noktadır. Akademik bir üslupla, öğretmen öğrenci resmiyetinde ve puan çıktılı yapılacak çalışmalar global kaygılardan ziyade not ve derece kaygısı oluşturacağından, bu durum ÇDGE'de istenilen bir olay değildir (Prensky ve Kuzu Demir, 2017). Öğrencilerin bireysel düşünmelerinin, şahsi başarılarına odaklanmalarının önüne geçilerek, onların yaşadıkları ortama duyarlı ve çevresiyle barışık, takım olgusu kazandırılmış bireyler olmaları için çabalanmalıdır (Prensky, 2016). Öğretmeninin doğru telkinleriyle yaşadığı dünyayı tanımaya çalışan öğrenci hayata farklı bir pencereden bakmaya başlayacak, yaşadığı dünyanın güzelliklerinin yanında problemleri de görecektir. Tespit ettiği bu problemleri sahip olduğu potansiyelle çözmeye çalışan öğrenci ödülünü, karşılaştığı sorunlara ürettiği çözümlerin sonucunda dünyanın güzelleştiğini gördükçe yaşadığı pozitif duyguyla alacaktır.

Türkiye'de ÇDGE yaklaşımının uygulanabilirliği ile ilgili bazı kurumlar öne çıkmaktadır. Bu çalışmada ÇDGE'nin Türkiye'de uygulanması sürecinde katkı sağlayabilecek potansiyellerin fırsatları ve engelleri incelenmiştir.

\section{1. ÇDGE Yaklaşımına Yönelik Türkiye'deki Fırsatlar}

Ülkemizde ÇDGE'nin mantığına uygun seçenekleri değerlendirildiğinde ve hedef kitlesinin K-12 kesimi olduğu dikkate alındığında, bu yaklaşımın Türkiye'de uygulanabilmesi konusunda katkı sağlayacak kurumlar arasında üç başlık ön plana çıkmaktadır. Bunlar; Milli Eğitim Bakanlığı (MEB), Türkiye Bilimsel ve Teknolojik Araştırma Kurumu (TÜBiTAK) ve Yükseköğretim Kurulu'dur (YÖK). Bu kurumların haricinde başka potansiyellerin de bulunabileceği söylenebilir. Ancak bu çalışma Prensky'nin belirlemiş olduğu çerçevede incelenmiştir. Örneğin; yaklaşımın K-12 düzeyindeki çocuklara yönelik olması nedeniyle diğer eğitim seviyesindeki potansiyeller değerlendirme dışı tutulmuştur.

\subsection{Milli Eğitim Bakanlığı (MEB)}

Ülkemizde hayata hazır, sağlıklı ve mutlu bireyler yetiştirmeyi hedefleyen Milli Eğitim Bakanlığı (MEB); "Düşünme, anlama, araştırma ve sorun çözme yetkinliği gelişmiş; bilgi toplumunun gerektirdiği bilgi ve becerilerle donanmış; milî kültür ile insanlığın ve demokrasinin evrensel değerlerini içselleştirmiş; iletişime ve paylaşıma açık, sanat duyarlılığı ve becerisi gelişmiş; öz güveni, öz saygısı, hak, adalet ve sorumluluk bilinci yüksek; gayretli, girişimci, yaratıcı, yenilikçi, barış̧̧ı, sağlıklı ve mutlu bireylerin yetişmesine ortam ve imkân sağlamaktır." misyonuyla faaliyetlerini yürütmektedir (MEB, 2017). MEB'in alt başlıklarından ve bileşenlerinden altı tanesi ÇDGE için Türkiye'deki potansiyel olarak görülerek aşağıda incelenmiştir.

\subsubsection{Değerler Eğitimi}

Okulların amacı öğrenciye sadece bilgiyi vermek değil, insanı insan yapan bütün değerleri de vermek olmalıdır. Çünkü iyi bir insan, iyi bir yaşam ve iyi bir toplum oluşturmak için eğitimde gösterilen çabalar çok önemlidir (Maslow, 1996). Eğitim yoluyla teşvik edilmesi gereken şey ise öğrencilerin hırsları değil, eylemsel tutkularıdır (Prensky ve Kuzu Demir, 2017). Dolayısıyla genç neslin dünyalarını güzelleştirmeleri için teknik ve donanımsal yeterliliğe sahip olmaları tek başına yeterli bir etmen olarak düşünülmemelidir. Çünkü hangi alanda olursa 
olsun sadece teknik bilgi konusunda yeterli donanıma sahip olmak, problemlere çözüm için yeterli değildir.

Türkiye'de ilk defa 2010 yılında Milli Eğitim Bakanlığı bünyesinde derslerde uygulanmaya başlayan değerler eğitimi, öğrencilere bilgi, beceri ve tutum kazandırmanın yanında onların temel insani değerleri kazanmış iyi birer vatandaş olarak yetişmelerini sağlamayı amaçlamaktadır (TTKB, 2017a). Bu amaçlar doğrultusunda değerler eğitimine okul öncesinden başlayarak eğitim - öğretimin her kademesinde yer verilmesi istenmekte ve bu konuda öğretmen, yönetici, öğrenci, aile ve çevre ile iş birliğine gidilmesi önerisinde bulunulmaktadır (TTKB, 2017b). Hatta TÜBiTAK, yıllardır organize ettiği Araştırma Projeleri başlıklarına son yıllarda "Değerler Eğitimi'ni" de ekleyerek bu kavrama gereken önemi vermeye başlamıştır. Tüm bu süreçlerde değerler eğitiminin en temel amacı sevgi, hoşgörü, doğruluk, sorumluluk, yardımlaşma, paylaşma gibi önemli konulardan bahsedilerek çocukların toplumsal, ahlaki, kültürel ve manevi değerleri kazanmaları sağlanmaktadır.

Değerler eğitiminin toplum ile ilgili farkındalık oluşturarak ideal birey olabilme konusunda ciddi manada katkı sağlayacağına inanılmaktadır. Yaşamın olmazsa olmazı insani değerlerimizi ve insanlığın ortak malı olan bilimi harmanlayarak kaliteli yaşama olumlu etki edebilecek değerler tespit edilmeli, bu süreçte karşılaşılabilecek sorunlar ve eksiklikler giderilerek insanlığın hizmetine sunulmalıdır (Akbaba, 2014). Bilgi bağlamındaki yeterliliklerin yanında insanda toplum ile ilgili duyarlılık sahibi olmalarını sağlayacak, bahsedilen tutkuyu ortaya çıkaracak aktivitelerin de olması gerekmektedir. Bu süreçte Milli Eğitim Bakanlığı'nın belirlediği değerler eğitimi başlıkları daha da geliştirilebilir. Hatta seçmeli olarak "Değerler Eğitimi" adı altında ayrı bir ders bile oluşturulabilir. Öğrencilerin küresel sorunları fark etmeleri sağlanarak toplumda yaşayan her bireyin, yaşadıkları dünyadan sorumlu oldukları gerçeğine dikkat çekilebilir. Bu farkındalığı oluşturduktan sonra problem teşkil edebilecek unsurlar tespit edilip, bu sorunlara yönelik ne tür çözüm önerileri getirilebileceği konusunda öğrencilerin düşünmeleri sağlanabilir. Bir sorunu keşfetmek, bir problemin farkına varmak en az o problemi çözmek kadar önemlidir. Çünkü o problemi gören duyarlı birey tek başına beceremese bile başkalarından destek alacak, yardım isteyecek, kısaca o yanlışı düzeltmek için elinden geleni yapacaktır.

\subsubsection{Bilim ve Sanat Merkezleri (BILSEM)}

Ülkemizde Bilim ve Sanat Merkezleri (BILSEM) ilk olarak 1992 yılında üstün ve özel yetenekli öğrencilerin eğitimi maksadıyla Milli Eğitim Bakanlığı'nın Özel Eğitim Rehberlik ve Danışma Hizmetleri Genel Müdürlüğü, yeni adıyla Özel Eğitim ve Rehberlik Hizmetleri Genel Müdürlüğü bünyesinde kurulmuştur (Sezginsoy, 2007). Normal okullardaki eğitime oranla daha farklı bir eğitim programı sunan bu kurumlarda; "öğrencilerin potansiyellerinin farkına varmaları sağlamak, ayrıca topluma katkıda bulunan bireyler olmalarını sağlamak" ana hedeflerden birkaçıdır. BiLSEM'e seçilen öğrenciler normal yaşıtlarından ayrılmadan ve toplumdan soyutlanmadan kendi okullarında eğitimlerine devam etmekte, arta kalan zamanlarda ve haftanın belirli günlerinde yetenekli oldukları alanları geliştirebilmek için bu kurumlara gelip eğitim alma hakkına sahip olmaktadırlar (Sezginsoy, 2007).

19 branşta atamanın olduğu BILLSEM'de görev yapmak isteyen öğretmenlerin seçimi; belge değerlendirmesi (\%60) ve sözlü sınav (\%40) başarılarına göre yapılmaktadır (BILSEM Öğretmen Kılavuzu, 2017). 2016 - 2017 Eğitim Öğretim Yılı itibariyle 80 ilde hizmet vermekte olan 106 BiLSEM'in öğrenci seçimi ise, Özel Eğitim ve Rehberlik Hizmetleri Genel Müdürlüğü'nün kontrolünde yapılmaktadır (BiLSEM Öğrenci Kılavuzu, 2017). İlk etapta 
okullarda sınıf öğretmenleri tarafından seçilen 1, 2 ve 3. Sınıf öğrencileri grup tarama sınavlarına girmeye hak kazanmaktadırlar. Grup tarama sınavına girip, belirlenen ölçütün üzerinde başarı sergileyen öğrenciler ise Milli Eğitim Bakanlığı tarafından belirlenen ölçütler doğrultusunda bireysel incelemeye tabi tutulurlar. Öğrencinin BILSEM'e yerleştirme kararı işte bu aşamada verilir.

BiLSEM'lerde 5 aşamalı eğitim programı uygulanmaktadır (Tebliğler Dergisi, 2016):
a) Uyum Programı
b) Destek Eğitimi Programı
c) Bireysel Yetenekleri Fark Ettirme Programı
d) Özel Yetenekleri Geliştirme Programı
e) Proje Üretimi Ve Yönetimi Programı

Öğrenciler tamamladığı her programın sonunda belge alarak bir sonraki programa geçmeye hak kazanmaktadırlar.

Türkiye'de özel yetenekli öğrencilerin tespit edilmesi ve potansiyellerinin ortaya çıkarılması konusunda kurum bazında rakipsiz olarak ifade edilebilecek BíLSEM'lerde yetişen genç beyinlerin ülkenin önemli değerleri olacaklarına inanılmaktadır. Eğitime farklı bir bakış açısı getiren bu kurumlarda öğrencilerin not korkusu yaşamadan, etkinlik tabanlı, eğlenceli bir şekilde vakit geçirmeleri sağlanarak ilgi ve yetenekleri doğrultusunda ürün ortaya koymaları hedeflenmektedir. Bu durum problem çözücü bir anlayışa sahip ÇDGE yaklaşımı için önem arz etmektedir. Özellikle BiLSEM eğitim programının son basamağı olan "Proje Üretimi Ve Yönetimi Programı" ile öğrencilerin kendilerine özgü tutku ve becerilerinden faydalanma imkanı doğabilir. Öğretmenlerin rehberliğinde veya bireysel duyarlılıklarının etkisiyle farkına vardıkları gerçek dünya problemlerine yönelik çözümleri bu basamakta ürüne dönüşebilir. Ortaya çıkan bu ürünlerin sayesinde dünya daha da güzelleşebilir. Kısaca BiLSEM'lerde öğrencilerin hizmetine sunulan imkanlar, karşılaşılan dünya sorunlarına çözüm önerisi üretebilmek için önemli bir etmendir. Dolayısıyla öğrencilerini, kendi dünyalarını nasıl iyileştireceklerini bilen güçlü bireyler haline dönüştüren BILSEM, ÇDGE'nin Türkiye'de uygulanması için önemli bir basamaktır.

\subsubsection{Bilişim Teknolojileri ve Yazılım Dersi}

Toplumun her alanında yoğun bir şekilde bilişim teknolojilerinin kullanılması, toplumda nitelikli bireylere intiyaç duyulmasını sağlamıştır. Bu ihtiyaçtan dolayı toplumun istediği nitelikli bireylerin yetiştirilmesi maksadıyla yeni eğitim bölümleri açılmış, mevcut bölümler geliştirilerek eğitim sistemi yeni teknolojilerle uyumlu hale getirilmeye başlanmıştır (Kılıçer ve Odabaşı, 2006). Bu gelişmelere paralel olarak ilk defa 1998 yılında bazı üniversitelerin eğitim fakülteleri bünyesinde Bilgisayar ve Öğretim Teknolojileri Eğitimi (BÖTE) bölümleri açılmaya başlanmıştır (Eren ve Uluuysal, 2012). Aynı zamanda 1997-1998 eğitim öğretim yılı itibariyle ilköğretim okullarında temel bilgisayar okuryazarlığının kazandırılması amacıyla Bilgisayar dersi müfredata eklenmiştir. Bu dersin günümüze kadar olan değişim süreci Şekil 2'de belirtilmiştir (BTE, 2017). 


\begin{tabular}{|c|c|c|c|c|c|c|c|c|c|c|c|}
\hline \multirow{2}{*}{ Yıl } & \multirow{2}{*}{ Ders Adı } & \multirow{2}{*}{ Durum } & \multirow{2}{*}{ Değerlendirme } & \multicolumn{8}{|c|}{ Ders Saati } \\
\hline & & & & 1 & 2 & 3 & 4 & 5 & 6 & 7 & 8 \\
\hline 1997 & Bilgisayar & Seçmeli & Not Var & - & - & - & $1-2$ & $1-2$ & $1-2$ & $1-2$ & $1-2$ \\
\hline 2005 & Bilgisayar & Seçmeli & Not Yok & 1 & 1 & 1 & 1 & 1 & 1 & 1 & 1 \\
\hline 2007 & $\begin{array}{c}\text { Bilișim } \\
\text { Teknolojileri }\end{array}$ & Seçmeli & Not Yok & 1 & 1 & 1 & 2 & 2 & 1 & 1 & 1 \\
\hline 2010 & $\begin{array}{c}\text { Bilişim } \\
\text { Teknolojileri }\end{array}$ & Seçmeli & Not Yok & - & - & - & - & - & 1 & 1 & 1 \\
\hline 2012 & $\begin{array}{c}\text { Bilişim } \\
\text { Teknolojileri } \\
\text { ve Yazılım }\end{array}$ & Seçmeli & Not Yok & - & - & - & - & 2 & 2 & 2 & 2 \\
\hline 2013 & $\begin{array}{c}\text { Bilişim } \\
\text { Teknolojileri } \\
\text { ve Yazılım }\end{array}$ & $\begin{array}{l}\text { 5-6 Zorunlu } \\
7-8 \text { Seçmeli }\end{array}$ & Not Var & - & - & - & - & 2 & 2 & 2 & 2 \\
\hline
\end{tabular}

Şekil 2. Bilişim Teknolojileri ve Yazılım Dersinin Tarihi

20 yıllık geçmişinde epey değişim gösteren bu dersin temel amacının, öğrencilerin bilgi ve iletişim teknolojilerini etik değerlere uygun, etkili ve üretken bir biçimde kullanabilmelerini sağlamak olduğu söylenebilir (Çelebi Uzgur, 2014). Son yıllara kadar seçmeli olan ve çoğu dönemlerde notu olmayan Bilişim Teknolojileri dersinin adı 2012 yılından itibaren Bilişim Teknolojileri ve Yazılım olarak değiştirilmiş ve içeriği yeniden yapılandırılarak taslak bir program oluşturulmuştur. Yeniden yapılandırılan eğitim programı; bilgi okuryazarlığı, teknoloji kullanımı ve üretiminde etik değerler, estetik, gizlilik, bilgi güvenliği ve siber suçlar gibi kişisel ve toplumsal açıdan önemli konuları içermektedir. Mevcut durumda yalnızca ofis yazııımlarının öğretildiği yapıdan uzaklaşılarak, yukarıda belirtilen konularla birlikte yetişen bireylerin yeni teknolojileri kendi kendilerine öğrenebilmelerine ve yeni teknolojilerin doğru kullanımı konusunda bilgilenmelerine olanak sağlayan bir yaklaşım benimsenmektedir (TTKB, 2017c). Bilişim Teknolojileri ve Yazılım dersi kapsamında kazandırılması hedeflenen bilgi, beceri ve değerlere ilişkin yeterlikler dört başlık altında incelenmektedir (TTKB, 2017c):
a) Bilişim Okur-Yazarlığı

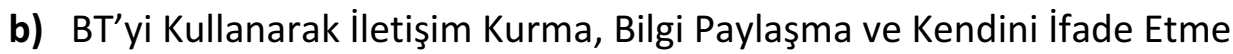
c) Araştırma, Bilgiyi Yapılandırma ve İşbirlikli Çalışma
d) Problem Çözme, Programlama ve Özgün Ürün Geliştirme

$\mathrm{Bu}$ ders kapsamında; öğrencilerin bilgi ve iletişim teknolojilerini doğru ve güvenli kullanabilecek seviyeye gelmelerini sağlamanın yanında, onların yazarlık ve programlama dillerini kullanabilecek seviyeye ulaşmaları hedeflenmektedir. Ayrıca çocukların bir problemi çözebilecek stratejiler geliştirmeleri ve bunu farklı bakış açıları ve yaklaşımlarıyla uygulamalarını sağlayacak seviyeye gelmeleri istenmektedir (TTKB, 2017c). 2017 - 2018 Eğitim Öğretim Yılı itibariyle güncellenen yeni öğretim programındaki dersin kazanımları incelendiğinde de anlaşılacağı üzere Bilişim Teknolojileri ve Yazılım dersinin ÇDGE yaklaşımına katkı sağlayabileceği düşünülmektedir. Çocukların teknolojiyi kullanarak dünyayı güzelleştirmelerine olanak sağlayacak altyapının Bilişim Teknolojileri ve Yazılım dersiyle 
mümkün olabileceği söylenebilir. Dersin "Yazılım" alt başlığı sayesinde öğrencilere programlama, kodlama ve robotik alanlarında eğitimler verilebilir ve çocukların problem çözücü birer "Maker" olmaları sağlanabilir. Ders kapsamında ortaya çıkan ürünler çeşitli yarışmalarda değerlendirilerek öğrencilerin daha ileriye gitmeleri konusunda ihtiyaç duyacakları pozitif etki sağlanabilir. Ayrıca teknolojinin bilinçli ve güvenli kullanımı konusunda öğrencilerde farkındalık oluşturmak, belirlediği bir sorunu teknoloji yardımıyla çözmeye çalışan çocukların daha sağlam adım atmalarına olanak sağlayacak ve onların işlerini kolaylaştıracaktır.

\subsubsection{Teknoloji ve Tasarım Dersi}

Okullarımızda sınav dersleri olarak nitelendirilebilecek temel derslerin (Örneğin ortaokullarda; Matematik, Türkçe, Fen Bilimleri, Sosyal Bilgiler, İngilizce gibi dersler) önemi elbette inkar edilemez. Ancak Görsel Sanatlar, Müzik, Teknoloji ve Tasarım gibi sanat odaklı genel beceri derslerinin de öğrencileri hayata daha iyi hazırladığı unutulmamalıdır. Çünkü kişiliğin oluşmasına katkısının yanında, yaratıcı olup karşılaşılabilecek sorunlar karşısında pratik çözüm önerileri getirebilme yeteneği elde edilmesinin yollarından biri de sanat eğitimidir (Canikoğlu, 2016). Sanat temalı bu derslerden Teknoloji ve Tasarım dersiyle gelecek nesillerin yaşadıkları çağın ihtiyaçlarına cevap verilmesi amaçlanmıştır. Ortaokullarda 7. ve 8. sınıflarda ikişer saat olan bu ders sayesinde çocuklara; ihtiyaçlar ortaya çıkmadan tahmin etme ve farklı sorunları yakalama, tespit edilen sorunlara yaratıcı çözümler geliştirme, somut bir ürün haline getirme, materyalin üretim aşamalarını belirleme ve üretme becerisi kazanmalarını sağlamak hedeflenmektedir. Teknoloji ve Tasarım Dersi Öğretim Programının genel amaçları şu şekilde açıklanmıştır (Teknoloji ve Tasarım, 2006):

“Öğrencilerin;

a) Merak eden, soru sormaktan çekinmeyen, gözlem ve araştırma yapmaya hevesli bir kişiliğe sahip olmaları,

b) Çevresindeki olay ve mekânlar arasındaki ilişkiyi kendine has bir bakış açısıyla değerlendirmeleri,

c) Karşılaştıkları güçlükleri yenmek için özgün çözümler üretmeleri,

d) Öz güvenini, hayal gücünü ve estetik duygularını geliştirmeleri,

e) Kendisi ve çevresi ile barışık, rekabete ve yeni yaşantılar edinmeye açık olmaları,

f) Bağımsız olarak düşünebilme alışkanlığı edinmeleri,

g) Özgün tasarımlar ortaya çıkarmaları,

h) Aldığı kararları değerlendirmeleri ve sorumluluklarını taşımaları,

i) Gelecek ile ilgili kurgular yapmaları,

j) Teknolojik gelişmeler karşısında kendilerini yenilemeleri,

k) Duygu ve düşüncelerini farklı yollarla ifade etmeleri amaçlanmaktadır."

Teknoloji ve Tasarım dersi üç kuşaktan oluşmaktadır. Bunlar Düzen, Kurgu ve Yapım kuşaklarıdır (Teknoloji ve Tasarım, 2006).

Düzen kuşağında; öğrencilerin hayattaki olaylara farklı açılardan bakmaları sağlanarak değerlendirme anlayışı geliştirmeleri sağlanır. Öğrenme sürecinde öğrencilerin yaratıcılıklarının gözlem, arama, sorgulama ve denemelerle gelişmesi sağlanır. Kısacası bu kuşakta psikomotor becerilerin ortaya çıkması için gerekli alt yapı oluşturulur. 
Kurgu kuşağında; öğrencilerin düzen kuşağında oluşturdukları temelin üzerinde yaratıcı düşüncelerini yapılandırırlar. Bu sayede öğrencilerin merak ve hayal ettikleri şeyleri değiştirmeyi, geliştirmeyi ve kolaylaştırmayı sağlayacak fikir ve hayal güçlerini yazarak somutlaştırmaları sağlanır.

Yapım kuşağında; öğrenciler sorunların çözümü için etkinlikler planlayarak ve uygulayarak somut tasarımlar yaparlar ve diğer kuşaklarda geliştirdikleri becerilerini somut bir ürünle ortaya çıkarmada kullanırlar. Sonrasında ise ortaya konulan ürünün hayata geçirilmesi ve kullanılması hedeflenir.

Yarının dünyasında yaşayacak insanların beklentilerini karşılamak ancak gözlemleyen, sorgulama yapan, araştıran, değerlendiren, yaratıcı yeteneklerini ortaya çıkaran, kısaca tasarım ve teknoloji için gereken zihinsel süreçleri yeterince aktif hâle getiren çalışmalarla mümkündür (Teknoloji ve Tasarım, 2006). Teknoloji ve Tasarım dersinin de bu süreçte yeri olduğu düşünülmektedir. Dolayısıyla bu dersin ÇDGE yaklaşımına katkı bağlamında atılabilecek adımların olduğu söylenebilir. Teknoloji ve Tasarım dersinde öğrencilerin çevrelerini gözlemlemeleri ve mevcut problemler ile olması gerekenleri fark ederek ve ona göre ürün ortaya koymaları istenmektedir. Bu problemlerle ilgili öğrencilerin daha duyarlı olmaları sağlanabilir. Bu sayede öğrenciler sırf not almak için değil de gerçekten bir soruna çözüm önerisi getirebilmek için ürün ortaya koymaya çalışacaklardır. Diğer öğrencilerin ilgisini çekmek ve teşvik etmek için ortaya konulan başarılı ürünler okullarda sergilenebilir veya EBA, okul siteleri gibi öğrencilerin ziyaret ettiği sayfalarda paylaşılabilir. İl bazında veya ülke genelinde yarışmalar düzenlenerek dereceye giren öğrenciler ödüllendirilebilir. Bunların yanında Teknoloji ve Tasarım dersi seviye bakımından uyarlanarak liselerde de ders olarak verilebilir. Özellikle Mesleki ve Teknik Anadolu Liseleri'nde ders olarak verildiği takdirde öğrencilerin potansiyelleri doğrultusunda yönlendirmeler yaparak yaratıcılıklarını ortaya çıkarmalarına katkı sağlanabilir.

\subsubsection{FATiH Projesi}

Ülkemizde teknolojinin eğitime entegrasyonu konusunda Fatih Projesi son yılların en önemli eğitim projesi olarak göze çarpmaktadır. 2010 yılında imzalanan protokolle hayata geçen Fatih Projesi, eğitim ve öğretimde fırsat eşitliğini sağlamak ve okullarımızdaki teknolojiyi iyileştirmek amacıyla bilişim teknolojileri araçlarının öğrenme - öğretme sürecinde daha fazla duyu organına hitap edilecek şekilde, derslerde etkin kullanımı maksadıyla başlatılmıştır (Fatih Projesi, 2017). Projenin donanım ayağı sayesinde her dersliğe etkileşimli tahta ve fiber internet bağlantısı hizmeti sunulmakta ve her öğretmen ve öğrenciye tablet pc verilmesi planlanmaktadır. Ayrıca proje kapsamında 2012 yılında yayın hayatına başlayan ve e - içerik konusunda öğretmen ve öğrencilerin ihtiyaçlarına cevap vermesi planlanan Eğitim Bilişim Ağı (EBA) dünyanın en geniş içeriğe sahip eğitim portalı unvanını almıştır.

Fatih Projesi Türkiye' de son yıllarda eğitim adına yapılmış en önemli projelerden birisidir. Dolayısıyla ÇDGE'nin Türkiye'de uygulanması sürecinde bu projeden destek alması çok anlamlı olacaktır. Her ne kadar Prensky eğitim sürecinde donanımsal veya içerik bakımından yapılan iyileştirmelerin ÇDGE'ye katkı sağlamayacağını ifade etmiş olsa da (Prensky ve Kuzu Demir, 2017), kapsamı itibariyle Fatih Projesi'nin hedefleri arasında öğrencileri edilgen konumdan etkin konuma taşıyarak genç girişimcilik ruhunu geliştirmesi bulunduğu unutulmamalıdır (Fatih Projesi, 2017). Ayrıca Fatih Projesi kapsamında okullara sağlanan donanımsal ve yazılımsal imkanlar, öğrencilerin STEM eğitimlerine önemli katkı sağlayacak bilişim teknolojileri araçları olarak görülmektedir. Eğitim sürecinde herkesin (öğretmen, öğrenci, 
idareci, veli vb.) bilişim teknolojilerinden eşit olarak faydalanabilme ve fırsat eşitliğine ulaşma ihtiyacını Fatih Projesiyle karşılamayı hedefleyen STEM uygulamaları, bu proje sayesinde geleneksel eğitim yaklaşımlarının yetersiz kaldığı günümüz bilgi ve teknoloji çağında bilişim teknolojilerini etkin olarak kullanmayı hedeflemektedir (STEM Eğitim Raporu, 2016).

Fatih Projesi kapsamındaki öneriler ele alınacak olursa; Küresel sorunlarla ilgili, değerler eğitimiyle ilgili oyunlar, uygulamalar geliştirilerek "EBA Dükkan” üzerinden öğrencilerin kullanıma açılabilir. Engelsiz EBA hareketi bünyesinde zihinsel ve fiziksel sorunlu kişilere yönelik içerikler ve materyaller geliştirilerek, dünyanın onlar için daha da güzelleşmesi sağlanabilir. Prensky, öğrenciler tarafından gerçekleştirilen devlet, çevre, teknoloji, akran yardımı, tarihi koruma gibi başlıkların da yer aldığı küresel projelerinin global bir referans veri tabanı hazırlamakta olduğunu belirtmiştir (Prensky ve Kuzu Demir, 2017). Prensky'nin de üzerinde çalıştığı, gerçek dünya problemlerinin belirtildiği global bir veri tabanının Türkiye uyarlaması EBA üzerinden tüm öğrencilere ulaştırılarak farkındalık yaratılabilir. Kısacası, Fatih Projesi kapsamında hizmete sunulan tüm bu teknolojiler gerçek dünya problemlerinin tespitinde ve çözüm önerisi üretme basamağında çocukların yardımcısı olabilir.

\subsubsection{STEM Uygulamaları}

Son yıllarda fen, teknoloji, mühendislik ve matematik alanlarında düşünen, üreten, sorgulayan ve yaratıc bireylere olan ihtiyacın gün geçtikçe artması nedeniyle, bu alanlarda öğretme ve öğrenme süreçlerine yönelik yeni ve farklı programlar ortaya çıkmaktadır (Yıldırım ve Altun, 2015). Bu uygulamaların son zamanlardaki popülaritesi artan değeri STEM olarak görülmektedir. Fen (Science), Teknoloji (Technology), Mühendislik (Engineering), Matematik (Mathematics) kelimelerinin baş harflerinden oluşan bu kavram Amerika Ulusal Bilim Vakfı'nda Eğitim ve İnsan Kaynakları müdürü olan Dr. Judith Ramaley tarafından ilk olarak 2001 yılında belirlenmiştir (Chute, 2009; Akt: Ceylan, 2014). STEM eğitimi, okul öncesi eğitimden yükseköğretime kadar tüm eğitim sürecini kapsayan disiplinler arası bir yaklaşım olarak kabul edilmiştir (Gonzalez ve Kuenzi, 2012; Akt: STEM Eğitim Raporu, 2016).

STEM'in amaçları arasında, öğrencilerin ilgilerini, dikkatlerini ve enerjilerini topluma hizmet edebilecekleri şekilde yönlendirmek ve öğrenmeye teşvik edecek soru ve problemlerle karşı karşıya kalmalarını sağlamak da bulunmaktadır (STEM Eğitim Raporu, 2016). Günümüz teknolojilerinin çoğunun bilimsel bir anlayışı temel alması, dolayısıyla genel anlamda fen, mühendislik ve matematiğin ürünü olması nedeniyle STEM'in teknoloji çağındaki önemi inkar edilemez.

Prensky, eski akademik kafa olduğu sürece, STEM gibi 21. Yüzyıl becerilerini kullanarak mevcut eğitim sistemini geliştirmenin fayda sağlamayacağını ifade etmektedir (Prensky ve Kuzu Demir, 2017). Ancak teknolojinin hayatın her alanına olduğu gibi eğitim alanına da değer kattığı unutulmamalıdır. STEM eğitimlerinde tıpkı ÇDGE'de istendiği gibi, öğretmenlerin rolünün öğrencilerinin üst düzey düşünecek, ürün geliştirebilecek, buluş yapabilecek seviyeye gelmelerini sağlarken rehberlik yapmak olduğu görülmektedir. Dolayısıyla STEM ile geliştirilen uygulamaların ÇDGE ile harmanlanmasıyla günümüz problemlerine çözüm sunarak dünyayı güzelleştirecek çeşitli ürünler ortaya çıkacaktır. Bu süreçte öncelikle STEM eğitimleriyle ilgili öncelikle Milli Eğitim Bakanlığı tarafından bir eylem planının hayata geçirilmesi gerekmektedir. Öğretmen ve öğrencilerin STEM'e yabancı olmaları nedeniyle çeşitli eğitimler planlanarak tanıtım ve bilgilendirme toplantıları yapılmalıdır. Bunun yanında çocuklara küçük yaşlardan itibaren Fen, Teknoloji, Mühendislik, Sanat ve Matematik disiplinleri arası bir bakış açısı 
kazandırılarak sorgulama, problem çözme, araştırma yapma, estetik bakış açısı ve ürün geliştirme becerilerinin kazandırılması amaçlanmalıdır (STEM Eğitim Raporu, 2016).

\subsection{Türkiye Bilimsel ve Teknolojik Araştırma Kurumu (TÜBiTAK)}

1963 yılında kurulan Türkiye Bilimsel ve Teknolojik Araştırma Kurumu (TÜBITAK) toplumumuzun yaşam kalitesinin artması ve ülkemizin gelişmesi maksadıyla bilim ve teknoloji alanlarında yenilikçi, yönlendirici, katılımcı ve paylaşımcı bir kurum olma vizyonunu benimsemektedir (TÜBITAK, 2017a). TÜBiTAK'ın alt başlıklarından iki tanesi ÇDGE yaklaşımı için Türkiye' deki potansiyel olarak görülerek aşağıda incelenmiştir.

\subsubsection{TÜBITAK Bilim Fuarları}

Milli Eğitim Bakanlığı ile imzalamış oldukları protokolle bilimsel eğitim etkinliklerini ve projelerini desteklemekte olan TÜBITAK'ın bu bağlamdaki bir diğer katkısının ise bu yıl 6.'sı düzenlenen TÜBITAK Bilim Fuarları olduğu görülmektedir. 5 - 12. sınıfta okumakta olan öğrencilerin ilgileri doğrultusunda belirledikleri konularla alakalı araştırma yaparak, araştırmalarının sonuçlarını sergileyebildikleri bu fuarlar öğrenciler için eğlenerek öğrenebilecekleri bir ortam oluşturmayı hedeflemektedir. TÜBITAK Bilim Fuarları hedeflerinden biri "Gerçek hayattaki soru ve sorunlara çözüm bulunmasında bilimin ve bilimsel çalışmaların öneminin öğrenciler tarafından uygulayarak / yaşayarak öğrenilmesinin sağlanmasıdır." (TÜBiTAK, 2017c). Bu hedef doğrultusunda okullar öğrencilerinin geliştirmiş oldukları çalışmaları TÜBITAK referansıyla sergilemek için başvuru yaparak destek talep etmektedirler. Kabul gören okullar TÜBiTAK'ın maddi desteğini de alarak öğrencilerinin projelerini sergiletmektedirler. Bu sergiler sayesinde öğrencileri bilimsel çalışmaların önemini hem uygulayarak hem de yaşayarak öğrenmektedirler.

\subsubsection{TÜBITAK Araştırma Projeleri}

TÜBITAK'ın en temel amaçlarından birinin genç araştırmacıları teşvik etmek, özendirmek ve desteklemek olduğu belirtilmektedir (TÜBITAK, 2017a). Bu amaç çerçevesinde TÜBiTAK Bilim İnsanı Destekleme Daire Başkanlığı tarafından lise öğrenimine devam etmekte olan öğrencileri temel, sosyal ve uygulamalı bilim alanlarında çalışmalar yapmaya teşvik etmek, çalışmalarını yönlendirmek ve mevcut bilimsel çalışmalarının gelişimine katkı sağlamak amacıyla 12 branşta Araştırma Projeleri düzenlemektedir (TÜBITAK, 2017b). Bu yıl 48.'si düzenlenen bu projelerle öğrencilerin kendi bilgi, beceri ve özgün fikirleriyle hayata geçirilmiş, geliştirilmiş ve danışman öğretmenlerin desteği ile tamamlanmış projeleri ilk etapta TÜBITAK'a gönderilerek başvuru yapılmaktadır. TÜBITAK'ın elemesi sonucunda yarışmaya değer bulunan projeler ise sonrasında bölgesel kategorilerde yarıştırılmaktadır. Bölgelerde dereceye giren projeler Ankara'ya davet edilmekte, alanlarında Türkiye birinciliği için birbirlerine rakip olmaktadırlar. 12 branşta Türkiye birincisi olan projeler ise ülkeyi temsilen yurt dışı yarışmalara katılmaya hak kazanmaktadırlar. Ayrıca TÜBiTAK'ın bu tarz aktivitelerinde belirli bir aşamaya gelen öğrenciler üniversiteye giriş sürecinde ek puan imkanı elde etmektedirler.

ÇDGE'nin Türkiye'de uygulanabilirliği konusundaki önemli potansiyellerden birinin de TÜBіTAK olduğu ifade edilebilir. TÜBITAK gerek yaptığı projelerle, gerekse sağladığı maddi imkanlarla genç araştırmacılara yapacakları çalışmalarda destek olmaktadır. Günümüzde K-12 düzeyindeki birçok okulda düzenlenmekte olan projelerin konu başlıklarının dünyayı geliştirecek, güzelleştirecek temalar olması konusunda teşvik olabilir. TÜBiTAK araştırma projeleri alanları genelde ders branşlarından (12 branş) oluşmakta ve her branşta farklı 
derecelendirme uygulanmaktadır. "Dünya" adıyla bir alan adı daha oluşturulup bu başlık altında hayatımızda olan bir problemin önüne geçecek, dünyayı güzelleştirecek projeler yarıştırılabilir. Çünkü çocuklarımız günümüzde o kadar güçlü ve yetenekli hale gelmişlerdir ki, aldıkları eğitimin çıktısı dünyayı geliştirmek olmalıdır (Prensky ve Kuzu Demir, 2017). Bu alanda TÜBiTAK'tan derece alan "dünyayı güzelleştiren çözümler" günümüzde binlerce ziyaretçisi olan EBA'da yayınlanarak herkese ulaştırılabilir. Bunun yanında öğrencilerin geliştirmiş oldukları bu tarz çalışmalarına patent almaları konusunda TÜBiTAK'ın yardımcı olması başarının tadını almanın yanında bilime giden yolda teşvik açısından öğrenciler için çok faydalı olacaktır.

\subsection{Yükseköğretim Kurulu (YÖK)}

Prensky'nin ÇDGE yaklaşımı K-12 düzeyindeki çocuklara yöneliktir. Dolayısıyla ilk etapta ön-lisans, lisans ve lisansüstü eğitimlerin verildiği üniversitelerin bu yaklaşıma katkı sağlayamayacağı düşünülebilir. Ancak son yıllarda üniversiteler bünyesinde kurulmaya başlayan ve gittikçe popülaritesi artan Çocuk Üniversiteleri'nin ÇDGE için potansiyel olabileceği düşünülmektedir.

\subsection{1. Çocuk Üniversiteleri Projesi}

İlk olarak 1993 yılında İngiltere'de kurulan çocuk üniversiteleri, lisans öncesi süreçte eğitim öğretim hayatına devam eden öğrencilere yönelik hizmetler sunmaktadır (Anadolu Üniversitesi, 2017). İngiltere'de kurulduktan yaklaşık 15 yıl sonrasında ülkemizde de duyulmaya başlayan Çocuk Üniversitesi projesi, üniversitelerin toplumun sadece bir kesimine yönelik değil, tüm kesimleriyle iletişim kurması ve ürün ortaya koyması gerektiği fikriyle başlatılan bir projedir (Özmen ve Kömürlü, 2013). Üniversitelerin bünyesinde oluşturulan ve üniversite hayatının zevkini almanın yanında, genç beyinleri erken yaşta bilimle ve sanatla tanıştırmayı hedefleyen çocuk üniversitelerinin toplumun gelişimi açısından ciddi katkılar sağlayacağına inanılmaktadır. Dünyada eğitim programlarında ve hitap ettiği yaş aralığına göre çeşitlilik gösteren çocuk üniversitelerinde belirli bir standart olmayıp, bu bölümlerin en önemli ortak paydasının topluma yararlı bir birey yetiştirmek olduğu söylenebilir. Örneğin İsviçre Basel Üniversitesi bünyesinde 2004 yılında kurulan bu bölümler sayesinde 7-14 yaş aralığındaki çocuklara eğitim tecrübesi sağlanırken ve 15-18 yaş aralığındaki çocuklarda ise okul dışında gönüllü çalışma fırsatı sunulurken (University Of Basel, 2017), Almanya Potsdam'daki Babelsberg Çocuk Üniversitesi'nde, 9-12 yaşları arasındaki çocuklara senaryo yazımı veya ses tasarımı gibi konuların yer aldığı kapsamlı film oluşturma eğitimleri verilmektedir (Deutschland.de, 2017). Mevcut çocuk üniversitelerini belirleyerek bir standart oluşturmak ve bu kurumların raporlarını, değerlendirmelerini analiz etmek masadıyla 2009 yılında Almanya'nın Tübingen kentinde bir konferans düzenlendi. Ayrıca bu konuda etkileşim ve bilgi aktarımını sağlamak amacıyla interaktif ve işbirliğine dayalı European Children's Universities Network (EUCU) web portalı oluşturdu (EUCU, 2017). Halen çocuk üniversiteleriyle ilgili birliktelik bu portal aracılığıyla sağlanmaktadır.

Ülkemizde Çocuk Eğitimi Uygulama ve Araştırma Merkezi, Yaşam Bilimleri Okulu, Çocuk Bilim Merkezi gibi farklı isimler de alan çocuk üniversiteleri ile ilgili ilgili çoğu üniversite kendilerini bu alanda öncü olarak nitelendirmektedirler. Ülkemizde bu kurumların amacı genel anlamda şu şekilde ifade edilmektedir (Tebliğler Dergisi, 2010): “

a) Toplum açısından bilimsel bilginin erişilebilirliğini artırmak, 
b) İlköğretim ve ortaöğretim düzeyindeki öğrencilerin ilgi duydukları bilimsel alanlarla ilgili güvenilir ve güncel bilgiyi, o alanın önde gelen bilim adamlarından almasını sağlamak,

c) Herhangi bir alanda mevcut müfredatın ötesinde bilgi sahibi olmak isteyen öğrencilere bu bilgiyi sağlamak,

d) Öğrencilerin meslek tercihinde bulunurken yapılacak hataların önceden giderilmesi ve bu yolla oluşabilecek kaynak dağılımı ve emek piyasası problemlerini ortadan kaldırmada katkı sağlamak,

e) Yapılacak eğitim-öğretim faaliyetleri ile ilgili tüm Üniversite mensuplarına uygulama ve araştırma yapma imkanı sağlamak."

Bu amaçlar doğrultusunda çocuk üniversitelerinde yaz okulu, kış okulu, deneyler, hafta sonu programları, bilimsel geziler, bilimsel modüller, workshoplar ve sosyal sorumluluk projeleri gibi etkinlikler hazırlanmaktadır (İstanbul Üniversitesi Çocuk Üniversitesi, 2017). Bu eğitimler üniversite imkanlarından yararlanmalarına fırsat verilen $\mathrm{K}-12$ seviyesindeki çocuklara üniversite öğretim üyeleri tarafından verilmektedir. MEB bünyesindeki okulların bir alternatifi olarak görülmemesi gereken çocuk üniversitelerinin öğrencilere yönelik eğitim açısından önemli katkı sağlayacağı söylenebilir.

Çocuk üniversitelerinin ÇDGE için önemli bir değer olduğu görülmektedir. Öğrencilerin ilgi duydukları alanlarda almak istedikleri eğitimi o branşın söz sahibi akademisyenler tarafından almaları kıymetli bir değerdir. Bu akademisyenler öğrencilere geleceğin bilim adamı olma konusunda yardımcı olabilirler. Çocukların sorun çözebilecek potansiyellerini geliştirmelerine katkıda bulunmanın yanı sıra, onlara çözebilecekleri "sorun" tespitiyle ilgili yönlendirmelerde bulunabilirler. Ayrıca geleceğin öğretmen adayları eğitim fakültesi lisans öğrencilerinin de çocuk üniversitesi eğitimleri alan çocuklarla buluşmaları sağlanarak, tecrübe kazanmaları sağlanabilir.

\section{2. ÇDGE Yaklaşımına Yönelik Türkiye'deki Engeller}

Prensky'nin ÇDGE yaklaşımı, çocukların kendilerine has potansiyellerini kullanarak dünyayı güzelleştirecek adımlar atmalarına olanak sağlayan önemli bir projedir. Türkiye'de bu yaklaşıma katkı sağlayabilecek çeşitli potansiyeller olduğu görülmektedir. Ancak potansiyel olarak görülen bu değerlerin verimini etkileyen bazı engellerin olduğunun da unutulmaması gerekmektedir. Bu bölümde ÇDGE yaklaşımının Türkiye'de uygulanabilirliği sürecinde karşımıza çıkabilecek engellerden bahsedilecektir.

ÇDGE çocuklara ciddi anlamda sorumluluk yüklemekte ve çocuklardan beklentileri yüksek tutmaktadır. Ülkemizin toplum yapısına bakılacak olursa, aileler her ne kadar çocukların kendini ifade edebilen, özgür bireyler olmalarını isteseler de onlara sorumluluk yüklemekten ve yetki vermekten kaçınmaktadırlar. Çocukların dünyalarını geliştirmelerine katkı sağlayan aileler olduğu gibi buna ket vuran aileler de karşımıza çıkabilmektedir. Dolayısıyla yüksek potansiyele sahip bile olsa, aileden yeterli desteği alamayan çocukların cevherlerinin ortaya çıkmayacağı düşünülmektedir. Aynı durum eğitim kurumları için de geçerlidir. Okul idareleri ve öğretmenlerin öğrencilere bu süreçte katkı sağlama ihtimali kadar engelleme ihtimali de bulunmaktadır. Burada belirtilmek istenen engelleme, müdahale ederek yapılabileceği gibi, yardıma ihtiyaç duyan bireye imkan olduğu halde yardımcı olmayarak da yapılabilir. 
Okullarda değerler eğitimi tüm derslerin içine entegre edilmiş olup, derslerde en az beş dakika zaman ayrılarak bu eğitimlerin verilmesi hedeflenmiştir. Öncelikle "Değerler Eğitimi" adı altında ayrı bir dersin olmaması, bu anlayışın yaygınlaşamaması adına önemli bir engel olarak düşünülmektedir. Bunun yanında, öğretmenlerin bir kısmının değerler eğitimine istenilen önemi vermediği, bunun da verimi düşürdüğü görülmektedir. Ayrıca bu eğitimlerle ilgili bir standart olmaması, illere, hatta okullara göre farklılık göstermesi verimlilik konusunda başka bir problem olarak görülmektedir.

Eğitime farklı bir bakış açısı getiren BíLSEM'ler üstün yetenekli öğrencilerin potansiyellerini ortaya çıkarmalarına sağlayan bir kurumdur. Ancak bu kurumların verimini düşüren bazı etmenler bulunmaktadır. Öncelikle BILSEM'lerde tam anlamıyla oturmuş bir sistem bulunmamaktadır. Çünkü BILLSEM'leri daha verimli hale getirme arayışı sürmekte, yönetmelik sürekli değişmektedir. Örneğin; BiLSEM'lere öğrenci seçimi birkaç sene öncesine kadar K-12 düzeyindeki her sınıf seviyesinde yapılırken 2016 yılında 2. ve 3. sınıflardan, 2017 yılında 1, 2 ve 3. Sınıflardan alım yapılmıştır. 2018 yılı için ise sadece 1. ve 2. sınıflardan seçilmesi planlanmaktadır. Dolayısıyla bu tarz değişimler BiLSEM'lerde öğrenci ve öğretmenleri olumsuz etkilediği düşünülmektedir. Bunun yanında BILSEM eğitim saatlerinin örgün eğitimin tamamlanmasından sonra akşama doğru başlaması, öğrencilerin yorgun bir şekilde bu kuruma gelmelerine ve buradaki eğitimlere tam anlamıyla adapte olamamalarına neden olmaktadır. Evlerine çok geç saatlerde dönen çocukların sosyal hayatları da olumsuz etkilenmekte, dinlenmeye, eğlenmeye vakit ayırmakta problem yaşamaktadırlar.

Bilişim Teknolojileri ve Yazılım dersi ile ilgili ÇDGE'nin işleyişinde karşılaşılabilecek problemlerden biri olarak bu derse okullarda gereken önemin verilmemesi gösterilebilir. 2013 yılına kadar seçmeli ve notu olmayan bir ders olması, halen bir ders kitabının bile olmaması bu derse olan bakış açısını olumsuz etkilemekte, "Sınav Dersleri" olarak nitelendirilen derslerin gölgesinde kalmasını sağlamaktadır. ÇDGE yaklaşımı ile ilgili bu ders kapsamında çocukların teknolojiyi kullanarak dünyayı güzelleştirebilecekleri düşünülmektedir. Ancak kodlama, programlama gibi alanlarda hakim dilin İngilizce olması çocukların önüne ayrı bir engel olarak çıkmakta, dolayısıyla eğitimlerin kalitesini düşürmektedir. Derslerin sadece okullarda olmamasından dolayı, her ailenin evinde çocukların uygulama yapabilecekleri bilgisayar, internet gibi ihtiyaçların olmaması veya robotik uygulamalar için ihtiyaç duyulacak materyallerin maliyetinin yüksekliği de ayrı bir engel olarak görülebilir.

Teknoloji ve Tasarım dersi, kapsamı itibariyle ÇDGE yaklaşımına en büyük katkıyı sağlayacak potansiyellerden birinin olacağına inanılmasına rağmen, en karamsar tablonun çizileceği potansiyel olabileceği de düşünülmektedir. An itibariyle üniversite düzeyinde mezun veren bir bölümü olmayan Teknoloji ve Tasarım dersinin atamaları Aile Ekonomisi ve Beslenme Öğretmenliği, Sınıf Öğretmenliği, Çiçek, Örgü Dokuma Öğretmenliği gibi farklı bölüm mezunlarıyla yapılmaktadır. Dolayısıyla alanında uzman eğitimcilerin olmaması sıkıntı olabilmekte, Teknoloji ve Tasarım dersine ataması yapılan diğer branş öğretmenlerinin derse oryantasyonu uzun zaman alabilmektedir. Sadece ortaokul bünyesinde 7. ve 8. sınıflarda olan Teknoloji ve Tasarım ders sayısının ve ulaştığı öğrenci grubunun azlığı da ayrı bir problem olarak görülebilir. Her ne kadar bu ders kapsamında öğrencilerin güzel fikirleri olsa da okullardaki fiziki imkanların yetersizliği nedeniyle ürün ortaya koyma sürecini çocuklar eğitim kurumlarında değil de dışarıda yapmak durumunda kalmaktadırlar. Dolayısıyla öğretmenlerin bu süreçte rehberlik yapmalarıyla ilgili çeşitli problemler ortaya çıkmaktadır. Bilişim Teknolojileri ve Yazılım dersinde de belirtildiği gibi "Sınav Dersleri" olarak adlandırılan 
kategoride yer almayan Teknoloji ve Tasarım dersine hem veli hem de öğrenciler tarafından gereken önemin verilmediği görülmektedir.

Türkiye'deki önemli eğitim projelerinden biri olan FATiH Projesi'nin verimliliğinin yanında projede bazı eksiklikler ve sıkıntıların olduğu da kabul edilmelidir. Örneğin eğitim sürecinde yaşanan donanımsal veya yazılımsal problemler eğitimi olumsuz etkilemektedir. Bunun yanında deney, gözlem, vs. gibi ufuk açıcı uygulamalarda kolaylık sağlayan e-içeriklerin kullanımı kolay olduğu için gerçek uygulamalara oranla daha çok tercih edilmesi de olumsuzluk olarak değerlendirilebilir. Çünkü imkân olduğu halde canlı olarak yapılabilecek bir deneyin veya uygulamanın gözleminden elde edilecek kazanımlarla, sırf kolay olduğu için tercih edilen animasyon ve simülasyonlardan elde edilen kazanımı kıyaslamak doğru olmayabilir. Ayrıca öğretmenlerin proje bileşenlerini kullanmaları için ihtiyaç duyulan gerekli teknoloji okuryazarlık seviyesine sahip olmamaları başka bir problem olarak görülmektedir.

Son yıllarda eğitimde önem kazanan ve dikkat çeken STEM'in uygulanmasında da bazı eksiklikler olduğu düşünülmektedir. STEM ile ilgili ilk akla gelen problemin bu uygulamalarda sanatın veya duygunun olmaması şeklinde ifade edilebilir. Her ne kadar STEM, STEAM'a (STEM alanlarına ek olarak, Art, Sanat Eğitimi) dönüştürülmeye çalıştırılsa da eylemsel tutkunun olmadığı mevcut eğitim sistemini geliştirme çabaları ÇDGE'ye yarar sağlamayacaktır (Prensky ve Kuzu Demir, 2017). Bunun dışında STEM'in uygulanabilirliği sürecinde ihtiyaç duyulacak teknolojilerde dışa bağlı olunması maliyeti artırmakta, fikir potansiyeli olsa bile maddi potansiyeli olmayan çocuklar bu durumdan olumsuz etkilenmektedir. STEM ile ilgili dile getirilebilecek bir başka problemin mevcut süreçte eğitime ve eğitim sistemine entegre edilmemesi olduğu söylenebilir. MEB müfredatının şu anda STEM eğitimlerine uygun olmaması da bir problem olarak görülmektedir. K-12 seviyesinde eğitim veren kurumlarda STEM kavramı ve mantığı pek bilinmemekte, bilinse bile sınava dayalı olan öğrenim sistemimizde sınava katkısı olmayacağı düşünülen STEM'e gerekli önem verilmemektedir. Dolayısıyla bireysel gayretlerin haricinde ilkokul, ortaokul ve liselerden STEM uygulamalarına yeterince destek gelmemektedir.

TÜBITAK Bilim Fuarları ve TÜBITAK Projelerinin temeli öğrencilerin yaratıcılıklarını kullanarak hazırladıkları çalışmalar üzerine kuruludur. Bu fuar ve projelerle ilgili problem olarak, ciddi bir hazırık süreci gerekmesi gösterilebilir. Bunun yanında öğrencilerin sunum yaptıkları zaman dinleyici katılımının azlığı motivasyonu düşürmektedir. Veya katılımcıların bu tarz organizasyonları bir nevi kermes gibi görmeleri motivasyonu etkileyen bir başka etmen olarak ifade edilebilir. Son yıllarda çoğu okul, yeterli potansiyeli ve hazırlığı olmasa bile TÜBITAK Bilim Fuarı düzenlemektedir. Bunun önemli nedenlerinden birisinin rekabet olgusundan kaynaklandığı düşünülmektedir. İstenilen sayıya ulaşmak için bilimsel araştırma yöntem ve teknikleri konusunda yetersiz öğretmen ve öğrenciler zorlanarak amatör denilebilecek çalışmalar ortaya çıkarılmaktadır. Bu da kaliteyi düşürmekte ve bilim fuarlarına bakış açısını olumsuz yönde etkilemektedir.

Çocuk Üniversiteleri projesi geleceğin bilim adamlarını bugünden yetiştirmeye başlamayı hedefleyen önemli bir projedir. Ancak ülkemizde henüz yeterince duyulmaması ve eğitime entegre edilememiş olması bir problem olarak görülmektedir. Yıllarca lisans ve lisansüstü eğitim veren akademisyenlerin K-12 yaş seviyesindeki öğrencilere eğitim verdiği bu projede hitap edilen kesimin yaşının alışılagelmişten farklı olması hocaların zorluk yaşama intimalini ortaya çıkaracaktır. Bu da projenin verimliliğine etki edecek önemli bir unsur olarak göze çarpmaktadır. 


\section{Sonuçlar}

Geleceğimizin teminatı çocuklarımızın iyi bir insan, topluma yararlı bir birey olmaları için bazı tohumların çocuklar küçükken atılması gerekmektedir. Çünkü çocuklar geleceğimizdir ve çocuğa yapılacak yatırım geleceğimize yapılan yatırımdır. Dolayısıyla çocukların dünyalarını, daha doğrusu hepimizin dünyasını geliştirebilmesi ve güzelleştirmesi için, üreten bir nesil olabilmeleri için onlara fırsat verilmesi gerekmektedir. Özellikle Piaget'in; çocukların, mantıklarını kullanarak, bağımsız olarak problem çözmeyi öğrendikleri ve soyut kavramları anlamaya başladıkları, hatta problemleri çözmeden önce zihinlerinde çözümü oluşturmaya başladıkları süreç olarak ifade ettiği Soyut İşlemler Dönemi'nde (11 yaş ve üzeri) olan çocuklara yapılacak olumlu yönlendirmeler onların gelişimi açısından önem arz etmektedir (Ayvacı ve Yurt, 2016). Çünkü çocukların bilimle erken yaşlardayken tanışması; sahip oldukları gelişim alanlarına katkı sağlaması ve gelişim alanlarına yeni değerler kazandırması açısından oldukça önemlidir (Eshach, Fried, 2005; Akt: Saçkes ve ark., 2011). Zaten Prensky de, ÇDGE yaklaşımı ile çocuklara bağımsızlık, eylemsel tutku ve güçlü bir başarma duygusu sunarak gelecek dünyaya nasıl uyum sağlayabileceklerini anlamalarına imkan tanınacağını belirtmektedir (Prensky ve Kuzu Demir, 2017).

ÇDGE yaklaşımı ile ilgili Türkiye'deki potansiyeller ele alındığında her ne kadar bazı problemler tespit edilmiş olsa da, karşımıza genel anlamda olumlu bir tablonun çıktığı görülmektedir. Çünkü Türkiye'de bu yaklaşımın uygulanabilirliğine katkı sağlayacak çeşitli kurumlar ve projeler bulunmaktadır.

Potansiyeller incelendiğinde kurum bazında MEB, TÜBITAK ve YÖK olmak üzere üç başlığın olduğu görülmektedir. Özellikle ülkemizde eğitimin temel taşı Milli Eğitim Bakanlığı'nın ÇDGE'ye katkı sağlayacak birçok alt maddelerinin olması MEB'i diğer potansiyellere oranla bir adım öne taşımaktadır. Değerler eğitimine hak ettiği değerin verilmesi, BiLSEM'lerdeki belirsizliği ortadan kaldıracak adımların atılması, Fatih Projesi bileşenlerinin verimliliğinin artırılması ve STEM'in eğitime entegresi MEB'i bu bağlamda daha verimli bir kurum haline getirecektir. Ayrıca Bilişim Teknolojileri ve Yazııım dersiyle Teknoloji ve Tasarım dersinin de müfredatının yenilenerek üzerlerindeki "gereksiz ders" intibasının ortadan kaldırılması bu derslerin geleceği açısından da çok daha olumlu olacaktır. Bunların yanında TÜBITAK bünyesindeki yapılan fuarlara, projelere verilen önemin artırılması, bu faaliyetlerde daha seçici olunması eğitimle bilimin kardeşliği açısından önemli bir fırsat olacaktır. ÇDGE'ye katkı bağlamında beklenti oluşturan bir diğer kurum olan çocuk üniversitelerinin ise, bu kurumunu henüz bilmeyen toplum tarafından benimsenmesi sağlanarak amacı doğrultusunda geleceğin bilim adamlarını yetiştirmeleri gelecekte dünyayı daha da güzelleştirecektir.

\section{Öneriler}

$\checkmark$ ÇDGE yaklaşımının yeni olması ve pek duyulmamış olması nedeniyle bu konuda farkındalık oluşturacak aktiviteler yapılmalıdır.

$\checkmark$ Çocuklara sorumluluk verilmeli, onlara dünyayı güzelleştirme konusunda fırsat tanınmalıdır.

$\checkmark$ "Sınav Dersleri" - "Diğer Dersler" ayrımını ortadan kaldıracak adımlar atılmalıdır.

$\checkmark$ Çocuk üniversitelerinin ve pek duyulmamış olması nedeniyle, bu oluşumdan daha çok faydalanılabilmesi adına farkındalık oluşturacak aktiviteler yapılmalıdır.

$\checkmark$ ÇDGE yaklaşımının önündeki engellerin aşılmasına yönelik somut adımlar atılmalıdır. 
$\checkmark$ Değerler eğitimi bir ders olarak eğitim müfredatına kazandırılabilir.

$\checkmark$ BiLSEM'lerin öğrenim saatlerinde düzenleme yapılabilir.

$\checkmark$ Çalışmada belirtilen potansiyeller ile ilgili bir araştırma çalışması yapılabilir.

\section{Kaynakça}

Akbaba, S. (2014). Psikolojik Sağlığı Koruyucu Rehberlik, Pegem Akademi, Ankara.

Anadolu Üniversitesi, (2017). Anadolu Üniversitesi Web Sitesi Çocuk Eğitimi Uygulama ve Araştırma Merkezi, Tarihçe. URL: http://www.cocuk.anadolu.edu.tr/v1/tarihce [Erişim Tarihi: 17.04.2017]

Ayvacı H. Ş., Yurt Ö. (2016). Çocuk ve bilim eğitimi, Çocuk ve Medeniyet Dergisi, cilt.1, ss.1528.

Bilgiç, H. G., Duman, D. ve Seferoğlu, S. S. (2011). Dijital yerlilerin özellikleri ve çevrim-içi ortamların tasarlanmasındaki etkileri. XIII. Akademik Bilişim Konferansı, 257-263. İnönü Üniversitesi, Malatya.

BíLSEM Öğrenci Kılavuzu, (2016). 2016-2017 Bilim ve Sanat Merkezleri Öğrenci Tanılama Kılavuzu, (s. 5).

BíLSEM Öğretmen Kılavuzu, (2017). Bilim ve Sanat Merkezlerine Öğretmen Seçme ve Atama Kılavuzu, (s. 9-10).

BTE, (2017). Bilişim Teknolojileri Eğitimcileri Derneği, BT Derslerinin Tarihçesi. URL:http://bte.org.tr/bt-derslerinin-tarihcesi/[ [Erişim Tarihi: 04.05.2017]

Canikoğlu, G. (2016). Görsel Sanatlar Dersi Öğretim Programındaki "Görsel IletişimBiçimlendirme " Öğrenme Alanının Uygulanmasında Ortaokul Görsel Sanatlar Öğretmenlerinin Görüşleri. (Yayınlanmamış Yüksek Lisans Tezi). Gazi Üniversitesi, Eğitim Bilimleri Enstitüsü, Ankara.

Ceylan, S. (2014). Ortaokul Fen Bilimleri Dersindeki Asitler Ve Bazlar Konusunda Fen, Teknoloji, Mühendislik Ve Matematik (FETEMM) Yaklaşımı Ile Öğretim Tasarımı Hazırlanmasına Yönelik Bir Çalışma. (Yayınlanmamış Yüksek Lisans Tezi). Uludağ Üniversitesi, Eğitim Bilimleri Enstitüsü, Bursa.

Chute, E. (2009). STEM education is branching out: Focus shifts from making science, math accessible to more than just brightest. Pittsburg Post-Gazette. URL: http://www.postgazette.com/news/education/2009/02/10/STEM-education-is-branchingout/stories/200902100165 [Erişim Tarihi: 26.03.2017]

Çelebi Uzgur, B. (2014). Bilişim Teknolojileri ve Yazılım Dersi Öğretim Programının Öğretmen Görüşlerine Göre Değerlendirilmesi (Ege Bölgesi Örneği). (Yayınlanmamış Yüksek Lisans Tezi). Muğla Sıtkı Koçman Üniversitesi, Eğitim Bilimleri Enstitüsü, Muğla.

Çetin Aydın, G., Başol, O. (2014). X Ve Y Kuşağı: Çalışmanın Anlamında Bir Değiş̧me Var Mı? Electronic Journal of Vocational Colleges. Cilt: 4, Sayı: 4, ss. 1-15.

Deutschland.de Web Sitesi, (2017). Childrens Universities In Germany. URL: https://www.deutschland.de/en/topic/knowledge/education-learning/childrensuniversities-in-germany [Erişim Tarihi: 17.04.2017] 
Erdem, A.R. (2004). Nasıl Bir Örgün Eğitim Sistemi?. Musa Gürsel (Ed.) Eğitime Illişkin Çeşitlemeler - 1 içinde (s. 73-85) Konya: Eğitim Kitabevi.

Erdem Okumuş, B. (2016) Kuşak Farkı Özelliklerine Göre Şekillenen Ofis Iç Mekân Tasarımı Kriterlerinin Irdelenmesi - Y Ve Z Kuşağı Üzerine Araştırma Ve Model Önerisi. (Yayınlanmamış Yüksek Lisans Tezi). Mimar Sinan Güzel Sanatlar Üniversitesi, Fen Bilimleri Enstitüsü, İstanbul.

Eren, E., Uluuysal, B. (2012). Bilişim Teknolojileri (BT) Öğretmenlerinin Mesleki Sorunları ve Çözüm Önerileri, Mersin Üniversitesi Eğitim Fakültesi Dergisi, Cilt 8, Sayı 3.

Eshach, H., Fried M. N. (2005). Should science be taught in early childhood? Journal of Science Education and Technology, 14(3), 315-336.

Fatih Projesi Web Sitesi, (2017). Eğitimde Fatih Projesi Hakkında. URL:http://fatihprojesi.meb.gov.tr/proje-hakkinda/ [Erişim Tarihi: 11.03.2017]

Gonzalez, H.B., Kuenzi J. (2012). Congressional Research Service Science, Technology, Engineering, and Mathematics (STEM) Education: A Primer, p. 2.

Hayta Önal, Ş. (2005). Bir Sorumluluk Eğitimi Programının Lise Dokuzuncu Sınıf Öğrencilerinin Sorumluluk Düzeylerine Etkisi. (Yayınlanmamış Yüksek Lisans Tezi). Uludağ Üniversitesi, Sosyal Bilimler Enstitüsü, Bursa.

İstanbul Üniversitesi Çocuk Üniversitesi, (2017). İstanbul Üniversitesi Çocuk Üniversitesi Kurumsal Stratejik Plan 2015-2018. (s. 13).

Kılıçer K., Odabaşı, H. F. (2006). "Bilgisayar Öğretmenliği: Etik Bunun Neresinde?" 6.Uluslararası Eğitim Teknolojileri Konferansı, Gazimağusa, KKTC, 19-21 Nisan 2006, Volume 2, ss, 1124-1129.

Khurmyet, G. (2016). Mobil Eğitim Teknolojisi Olarak Tablet Bilgisayarın Etkin Öğrenim Amaçlı Kullanımı: Özel Ortaöğretim Kurumları Üzerine Bir Araştırma. (Yüksek Lisans Tezi). Marmara Üniversitesi / Sosyal Bilimler Enstitüsü, İstanbul.

Maslow, A. (1996). Dinler, Değerler ve Doruk Deneyimler. (Çev: Sönmez ve Koray) Kuraldışı Yayınları, İstanbul.

MEB, (2017). Milli Eğitim Bakanlığı Vizyon, Misyon.

URL: http://www.meb.gov.tr/vizyon-misyon/duyuru/8851 [Erişim Tarihi: 29.04.2017]

Özmen, F., Kömürlü, F. (2013). Türkiye'de Üstün Zekalı ve Yetenekli Öğrencilerin Eğitimine iliş̧kin Politika ve Uygulamalar. Inönü Üniversitesi Eğitim Fakültesi Dergisi. 14(2), 35-56.

Prensky, M. (2001a). Digital natives, digital immigrants. On the Horizon, 9(5), 1-5.

Prensky, M. (2001b). Digital Game-Based Learning. New York: McGraw-Hill.

Prensky, M. (2005). Listen to the natives. Educational Leadership: Learning in the Digital Age. $63(4), 8-13$.

Prensky, M. (2016). Education To Better Their World - The Emerging Vision Of A New K-12 Education For The Empowered Kids Of Tomorrow. Asia - Pacific Annual Conference. Hyderabad, India. 
Prensky, M., Kuzu Demir, E. B. (2017). “Çocukların Dünyalarını Geliştirme Eğitimi” Yoluyla 21. Yüzyıl Çocuklarımızın Gücünü Ortaya Koymak. Ferhan Odabaşı (Ed.) Dijital Yaşamda Çocuk içinde (s. 193-204) Ankara: Pegem Akademi.

Resmi Gazete, (2010). İstanbul Üniversitesi Çocuk Eğitimi Uygulama ve Araştırma Merkezi Yönetmeliği. Resmi Gazete. 27506.

Saçkes, M., Trundle, K. C., Bell, R. L. \& O'Connell, A. A. (2011). The influence of early science experience in kindergarten on children's immediate and later science achievement: evidence from the Early Childhood Longitudinal Study. Journal of Research in Science Teaching, 48(2), 217-235.

Sezginsoy, B. (2007). Bilim ve Sanat Merkezi Uygulamasının Değerlendirilmesi.

(Yayınlanmamış Yüksek Lisans Tezi). Balıkesir Üniversitesi, Sosyal Bilimler Enstitüsü, Balıkesir.

Şimşek, N. (1997). Derste Eğitim Teknolojisi Kullanımı. Ankara: Anıl Matbaa Ve Ciltevi.

TTKB, (2017a). Milli Eğitim Bakanlığı Talim Terbiye Kurulu Başkanlığı "illk Ders" Konulu Genelge, 2010/53.

TTKB, (2017b). 18. Milli Eğitim Şurası Kararları, Sanat, Beceri Ve Değerler Eğitimi Bölümü Madde:35.

TTKB, (2017c). Ortaokul ve Imam Hatip Ortaokulu Bilişim Teknolojileri ve Yazılım Dersi (5, 6, 7 ve 8. Sınıflar) Öğretim Programı. URL: http://ttkb.meb.gov.tr/program2.aspx [Erişim Tarihi: 06.05.2017]

Tebliğler Dergisi (2016). Bilim Ve Sanat Merkezleri Yönergesi, Milli Eğitim Bakanlığı Tebliğler Dergisi, 2710.

Teknoloji ve Tasarım, (2006). Illköğretim Teknoloji ve Tasarım Dersi Öğretim Programı ve Kılavuzu. Ankara: MEB, Devlet Kitapları.

TÜBітAK (2017a). TÜBіTAK Tarihçesi. URL: $\underline{\text { https://www.tubitak.gov.tr/tr/icerik-hakkimizda }}$ [Erişim Tarihi: 15.03.2017]

тÜBITAK (2017b). TÜBiTAK Araştırma Projeleri URL: https://www.tubitak.gov.tr/tr/yarismalar/icerik-lise-ogrencileri-arastirma-projeleriyarismasi [Erişim Tarihi: 31.03.2017]

TÜBITAK (2017c). TÜBіTAK Bilim Fuarları URL: $\underline{\text { http://bilimiz.tubitak.gov.tr/bilimFuari.htm }}$ [Erişim Tarihi: 15.03.2017]

Yıldırım, B., Altun, Y. (2015). STEM Eğitim ve Mühendislik Uygulamalarının Fen Bilgisi Laboratuar Dersindeki Etkilerinin İncelenmesi. El-Cezerî Fen ve Mühendislik Dergisi, 2 (2); 28-40. 